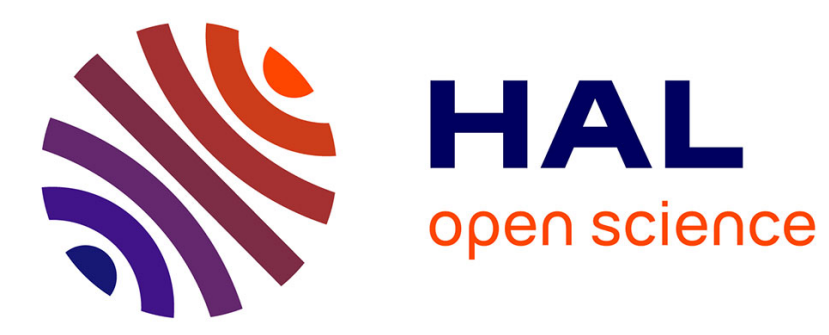

\title{
Potential of innovative ceramics for turbine applications.
}

A. Jankoviak, R. Valle, M. Parlier

\section{To cite this version:}

A. Jankoviak, R. Valle, M. Parlier. Potential of innovative ceramics for turbine applications.. ODAS, May 2013, PALAISEAU, France. hal-01057786

\section{HAL Id: hal-01057786 \\ https://hal-onera.archives-ouvertes.fr/hal-01057786}

Submitted on 25 Aug 2014

HAL is a multi-disciplinary open access archive for the deposit and dissemination of scientific research documents, whether they are published or not. The documents may come from teaching and research institutions in France or abroad, or from public or private research centers.
L'archive ouverte pluridisciplinaire HAL, est destinée au dépôt et à la diffusion de documents scientifiques de niveau recherche, publiés ou non, émanant des établissements d'enseignement et de recherche français ou étrangers, des laboratoires publics ou privés. 


\begin{tabular}{lllllllllll}
$\mathrm{T}$ & $\mathrm{I}$ & $\mathrm{R}$ & $\dot{E}$ & & $\grave{A}$ & & $\mathrm{P}$ & $\mathrm{A}$ & $\mathrm{R}$ & $\mathrm{T}$ \\
\hline
\end{tabular}

\title{
Potential of innovative ceramics for turbine applications.
}

\author{
A. Jankowiak, R. Valle, M. Parlier
}

\section{ODAS}

PALAISEAU , FRANCE

27-29 mai 2013

\section{ONERA}

THE FRENCH AEROSPACE LAB 

Potential of innovative ceramics for turbine applications.

\title{
Potentiel de céramiques innovantes pour des applications turbines
}

\author{
par
}

\author{
A. Jankowiak, R. Valle, M. Parlier
}

\section{Résumé traduit :}

L'amélioration du rendement thermique des turbines à gaz d'aéronefs et des systèmes thermiques de production d'électricité est d'un grand intérêt pour l'industrie. Malgré les différentes études menées pour augmenter leur réfractarité, l'utilisation de superalliages à base de nickel à des températures au-delà de $1150{ }^{\circ} \mathrm{C}$ sera difficile. Pour des températures plus élevées, de nouveaux matériaux thermostructuraux sont nécessaires. Dans ce contexte, les céramiques présentent de nombreux avantages par rapport aux superalliages à base nickel: densité plus faible, meilleure résistance à l'oxydation et à l'abrasion. Deux sortes de céramiques sont étudiées à l'Onera: matériaux à base de Si3N4 et les céramiques eutectiques obtenues par solidification dirigée pour une utilisation respectivement jusqu'à 1500 et $1700^{\circ} \mathrm{C}$. Pour les deux matériaux, l'amélioration de la ténacité est un défi. Cet article présente les techniques d'élaboration, la microstructure et les propriétés mécaniques de ces matériaux. 



\title{
Potential of innovative ceramics for turbine applications
}

\author{
A. Jankowiak*, R.Valle, M. Parlier \\ ONERA - The French Aerospace Lab, F- 92322 Châtillon, France
}

* corresponding author: aurelie.jankowiak@onera.fr (copy to: michel.parlier@onera.fr)

\begin{abstract}
:
Improving the thermal efficiency of aircraft gas turbines and of thermal power generation systems is of great interest for industry. Despite the various studies performed to increase their heat-resistance, the use of nickel-based superalloys at temperatures beyond $1150^{\circ} \mathrm{C}$ will be difficult. For higher temperatures, new high temperature structural materials are required. In this context, ceramics offer many advantages compared to Ni-based superalloys: a lower density and a better resistance to oxidation and abrasion. Two kinds of ceramics are investigated at Onera: $\mathrm{Si}_{3} \mathrm{~N}_{4}$ based materials for use up to $1500^{\circ} \mathrm{C}$ and directionally solidified eutectic (DSE) ceramics up to $1700^{\circ} \mathrm{C}$. For both materials, improving toughness is a challenge. This paper presents the processing techniques, the microstructural features and the mechanical properties.
\end{abstract}

\section{Introduction}

Over the last decades, considerable efforts have been devoted to the improvement of the temperature capability of metallic superalloys which cannot henceforth exceed $1150^{\circ} \mathrm{C}$. The desire to reduce operating costs including fuel consumption and maintenance, constitutes technological driving forces that are becoming more and more important. Indeed, a substantial increase in the temperature capability of turbine materials would allow for significant performance enhancements. High temperature materials represent one major enabler in the long-term for most, if not all, future engine improvements. In this context, new materials families are being developed to allow for a significant increase (more than $150^{\circ} \mathrm{C}$ ) in material operating temperatures. Ceramic materials are promising candidates for structural applications at higher temperatures under high stresses in oxidizing and corrosive environments. Unfortunately, sintered ceramics are brittle and the use of ceramic fibres in ceramic matrix composites (CMCs) is limited by grain growth; therefore, improving toughness is of major interest. Two new material systems, $\mathrm{Si}_{3} \mathrm{~N}_{4}$ based ceramics and directionally solidified eutectic (DSE) ceramics show promising properties that would allow for their use in future turbines. The first material is expected to be operating up to $1500^{\circ} \mathrm{C}$ [1] and is now used in highly efficient small land-based turbines due to optimization of composition, microstructure, processing and coatings. Major manufacturers (Solar Turbines, Ingersoll Rand, Honeywell, General Electric, Pratt \& Whitney, Capstone-Microturbines, etc.) have had tens of thousands of service hours of experience with them. However, this material exhibits some drawbacks: difficult and expensive machining due to its hardness and its high electrical resistance $\left(\sim 10^{14} \Omega . \mathrm{cm}\right)$, lack of long term reliability in severe environments, insufficient level of fracture toughness to overcome failure induced by foreign object impacts (when used for engine parts). According to previous studies, one way to improve mechanical properties and promote easy machining of $\mathrm{Si}_{3} \mathrm{~N}_{4}$ is to combine this ceramics with $\mathrm{MoSi}_{2}$ [2]-[10]. Development of $\mathrm{Si}_{3} \mathrm{~N}_{4}-\mathrm{MoSi}_{2}$ composites is in progress at Onera [11]. Directionally solidified eutectics, prepared by unidirectional solidification of oxides from the melt, add new potentialities to the advantages of sintered ceramics and CMCs. Studies performed on eutectic compositions between alumina and rare-earth (RE) oxides have led to in situ composites consisting in two entangled three-dimensional and continuous interconnected networks of two single-crystal eutectic phases. After solidification, the eutectic phases are alumina and either a perovskite phase $\mathrm{REAlO}_{3}$ (RE: Gd, Eu) or a garnet phase $\mathrm{RE}_{3} \mathrm{Al}_{5} \mathrm{O}_{12}$ (RE: Y, Yb, Er, Dy). In the case of ternary systems, cubic zirconia is added to improve the fracture toughness, this phase being present as a dispersoid. The binary and ternary systems both exhibit outstanding mechanical properties, such as a flexural strength that is constant up to temperatures close to the melting point (no amorphous phase at the interfaces between the different phases), good creep resistance, stability of the microstructure, no chemical reaction between the constituent phases and intrinsic resistance to oxidation [12]-[17].

The development status will be presented in this paper for both nitride based materials and directionally solidified eutectic ceramics. 


\section{$2 \quad \mathrm{Si}_{3} \mathrm{~N}_{4}$ based materials}

\subsection{Context}

Several european universities and research centres in relation with major engine manufacturers pooled their expertise within the European Union funded HYSOP project ("Hybrid Silicide based Lightweight Components for turbine and energy applications") under the coordination of Onera. This project aimed at improving the mechanical properties (toughness, creep) and oxidation resistance of $\mathrm{Nb}$-Si based alloys and $\mathrm{Si}_{3} \mathrm{~N}_{4}$ based materials. Within this project, Onera has to develop optimized compositions of $\mathrm{Si}_{3} \mathrm{~N}_{4}-\mathrm{MoSi}_{2}$ materials with advanced processes to manufacture materials with adequate microstructures and properties. This paper is an outline of the work which has already been done at Onera on these materials.

\subsection{Processing and experimental means}

Six compositions of $\mathrm{Si}_{3} \mathrm{~N}_{4}-\mathrm{MoSi}_{2}$ baseline materials were manufactured using spark plasma sintering (HP D 25, FCT System GmbH, MATEIS Laboratory, Lyon, France). The ceramic composites were produced from the following commercial powders: $\mathrm{MoSi}_{2}$ (H.C. Starck, grade B), $\mathrm{Si}_{3} \mathrm{~N}_{4}$ (H.C. Starck, grade M11), $\mathrm{MgO}, \mathrm{CeO}_{2}, \mathrm{Al}_{2} \mathrm{O}_{3}, \mathrm{Y}_{2} \mathrm{O}_{3}$ and $\mathrm{Lu}_{2} \mathrm{O}_{3}$ [11]. Studied compositions with three kinds of sintering aids are reported in Table 1.

\begin{tabular}{|l|l|}
50 vol. $\% \mathrm{Si}_{3} \mathrm{~N}_{4}-50$ vol\% $\mathrm{MoSi}_{2}$ & +3 wt. $\% \mathrm{Al}_{2} \mathrm{O}_{3} / 4$ wt. $\% \mathrm{Y}_{2} \mathrm{O}_{3}$ \\
\cline { 2 - 2 } \multirow{2}{*}{$\begin{array}{l}\text { and } \\
70 \text { vol. } \% \mathrm{Si}_{3} \mathrm{~N}_{4}-30 \text { vol\% } \mathrm{MoSi}_{2}\end{array}$} & +10 wt. $\% \mathrm{Lu}_{2} \mathrm{O}_{3}$ \\
\cline { 2 - 2 } & +5 wt. $\% \mathrm{MgO} / 5$ wt. $\% \mathrm{CeO}_{2}$ \\
\hline
\end{tabular}

Table 1: Compositions of $\mathrm{Si}_{3} \mathrm{~N}_{4}-\mathrm{MoSi}_{2}$ materials and the different sintering aids.

Powders are attrition-milled in ethanol using $\mathrm{Si}_{3} \mathrm{~N}_{4}$ media for 8 hours in a high-density polyethylene tank. Then the mixtures are dried using rotary evaporation and sieved through a $50 \mu \mathrm{m}$ sieve. Pellets, $45 \mathrm{~mm}$ in diameter and $3 \mathrm{~mm}$ in thickness, were sintered in a graphite die in $\mathrm{Ar}$ atmosphere under $30 \mathrm{MPa}$ with a heating rate of $150^{\circ} \mathrm{C} / \mathrm{h}$ up to $1550-1750^{\circ} \mathrm{C}$ (Table 2).

\begin{tabular}{lccccc}
\hline Material (vol. \%) & Sintering aids & Reference & $\begin{array}{c}\text { Thermal } \\
\text { treatment }\end{array}$ & Density $\mathbf{g} / \mathbf{c m}^{\mathbf{3}}$ & $\begin{array}{c}\mathbf{d} / \mathbf{d}_{\text {th }} \\
(\mathbf{\%})\end{array}$ \\
\hline $\mathbf{5 0 - 5 0} \mathbf{S i}_{3} \mathbf{N}_{\mathbf{4}}-\mathbf{M o S i}_{\mathbf{2}}$ & $\mathrm{Al}_{2} \mathrm{O}_{3}-\mathrm{Y}_{2} \mathrm{O}_{3}$ & $\mathrm{SM} 55 \mathrm{AY}$ & $1550^{\circ} \mathrm{C} / 5 \mathrm{~min}$ & 4.43 & $>99$ \\
$\mathbf{5 0 - 5 0} \mathbf{S i}_{3} \mathbf{N}_{\mathbf{4}}-\mathbf{M o S i}_{\mathbf{2}}$ & $\mathrm{Lu}_{2} \mathrm{O}_{3}$ & $\mathrm{SM} 55 \mathrm{Lu}$ & $1550^{\circ} \mathrm{C} / 15 \mathrm{~min}$ & 4.83 & 96 \\
$\mathbf{5 0 - 5 0} \mathbf{S i}_{3} \mathbf{N}_{\mathbf{4}}-\mathbf{M o S i}_{\mathbf{2}}$ & $\mathrm{MgO}_{-} \mathrm{CeO}_{2}$ & $\mathrm{SM} 55 \mathrm{MC}$ & $1550^{\circ} \mathrm{C} / 5 \mathrm{~min}$ & 4.55 & 95.2 \\
$\mathbf{7 0 - 3 0} \mathbf{S i}_{3} \mathbf{N}_{\mathbf{4}}-\mathbf{M o S i}_{\mathbf{2}}$ & $\mathrm{Al}_{2} \mathrm{O}_{3}-\mathrm{Y}_{2} \mathrm{O}_{3}$ & $\mathrm{SM} 73 \mathrm{AY}$ & $1700^{\circ} \mathrm{C} / 15 \mathrm{~min}$ & 3.99 & 97.8 \\
$\mathbf{7 0 - 3 0} \mathbf{S i}_{3} \mathbf{N}_{\mathbf{4}}-\mathrm{MoSi}_{\mathbf{2}}$ & $\mathrm{Lu}_{2} \mathrm{O}_{3}$ & $\mathrm{SM} 73 \mathrm{Lu}$ & $1750^{\circ} \mathrm{C} / 15 \mathrm{~min}$ & 4.28 & 96.2 \\
$\mathbf{7 0 - 3 0} \mathbf{S i}_{\mathbf{3}} \mathbf{N}_{\mathbf{4}}-\mathbf{M o S i}_{\mathbf{2}}$ & $\mathrm{MgO}-\mathrm{CeO}_{2}$ & $\mathrm{SM} 73 \mathrm{MC}$ & $1700^{\circ} \mathrm{C} / 15 \mathrm{~min}$ & 4.03 & 95.6 \\
\hline
\end{tabular}

Table 2: Compositions, sintering conditions and densification level of $\mathrm{Si}_{3} \mathrm{~N}_{4}-\mathrm{MoSi}_{2}$ materials.

For each sample, three rectangular bars of mean dimensions $35 \mathrm{~mm}$ x $5 \mathrm{~mm}$ x $1.75 \mathrm{~mm}$ were cut and used for characterizations. Density and open porosity were measured using Archimede's principle and the densification rate is considered as the ratio between the measured density and the theoretical density of the powder. Mechanical properties have been determined using three-point bending tests and Vickers' indentation $(10 \mathrm{~kg})$ on samples polished down to $0.25 \mu \mathrm{m}$ on the side where fracture was expected to initiate. Measurement of the Young's modulus has been carried out by taping with a Grindosonic Mk5i, as described in ASTM Standard E1876-07.

Three-point bending tests have been performed at room temperature on a Zwick facility with a crosshead displacement speed of $0.3 \mathrm{~mm} / \mathrm{min}$. Three tests have been performed for each composition. Toughness $\left(\mathrm{K}_{\mathrm{c}}\right)$ was calculated according to Equation 1 using data from Vickers' indentation.

$$
K_{c}=0.0154 \frac{F}{c^{3 / 2}} \sqrt{E / H_{v}} \text { MPa.m }^{1 / 2}
$$

Equation 1

with: $\mathrm{F}$ the force $(\mathrm{N}), \mathrm{H}_{\mathrm{v}}$ Vickers' hardness (GPa), E the Young's modulus (GPa), c the average crack length from the centre of the indent to the crack tip $(\mu \mathrm{m})$. 
SEM observations were performed on $1 / 4 \mu \mathrm{m}$ - polished cross-sections using a Carl Zeiss DSM 962 facility, equiped with EDS for local analyses. Phases were characterized using a Bruker AXS D8 Advance diffractometer (Bragg Brentano configuration). The diffraction range was from $8^{\circ}$ to $94^{\circ}$ with a $0.01^{\circ}$ scanning step. Semi-quantitative analyses of patterns allow determining an $\alpha-\mathrm{Si}_{3} \mathrm{~N}_{4} / \beta-\mathrm{Si}_{3} \mathrm{~N}_{4}$ ratio $(\alpha / \beta)$.

\subsection{Microstructures}

The spark plasma sintered composites are fully dense with an open porosity level lower than $1 \%$ and a final density ranging from 4 to $4.8 \mathrm{~g} . \mathrm{cm}^{-3}$, depending on the composition (Table 2). These results are confirmed by SEM observations on polished cross sections perpendicular to the pressing direction, in which few intergranular closed pores are detected (Figure 1). The microstructures consist in well dispersed $\mathrm{MoSi}_{2}$ (white) and $\mathrm{Si}_{3} \mathrm{~N}_{4}$ (dark) particles surrounded by a grain boundary phase. The differences observed between the compositions are due to both the nature and the amount of sintering aids. No reaction occurs between $\mathrm{MoSi}_{2}$ and $\mathrm{Si}_{3} \mathrm{~N}_{4}$ [18] and no cracks are detected despite the thermal expansion mismatch between the two compounds $\left(\alpha_{\mathrm{MoSi} 2} \sim 9.10^{-6 \circ} \mathrm{C}^{-1}\right.$ and $\left.\alpha_{\mathrm{Si3N} 4} \sim 3.10^{-6 \circ} \mathrm{C}^{-1}\right)$ [11]. Sintering aids are located at the grain boundary and can limit the strains during sintering. Moreover, internal stresses can be afforded by plastic deformation of $\mathrm{MoSi}_{2}$ too. In the case of materials with $\mathrm{Lu}_{2} \mathrm{O}_{3}$, a crystalline phase $\mathrm{Lu}_{2} \mathrm{Si}_{2} \mathrm{O}_{7}$ is revealed by XRD and $\mathrm{MgO}$ and $\mathrm{CeO}_{2}$ are still detected in SM55MC and SM73MC after sintering. In the SM55AY and SM73AY composites, no crystalline phases are revealed, so the grain boundary phase is supposed to be totally amorphous. The acicular $\beta-\mathrm{Si}_{3} \mathrm{~N}_{4}$ is clearly developed for all compositions with high content of $\mathrm{Si}_{3} \mathrm{~N}_{4}$ and this is confirmed by XRD results. For compositions with lower amount of $\mathrm{Si}_{3} \mathrm{~N}_{4}$, the $\alpha$-phase is still detected by XRD due to the lower sintering temperature (Table 3). The growth of the acicular phase is often desirable to increase toughness because this kind of grains induces crack deflection. Low amounts of $\mathrm{Mo}_{5} \mathrm{Si}_{3} \mathrm{C}$ were detected in all cases probably due to the graphite die.
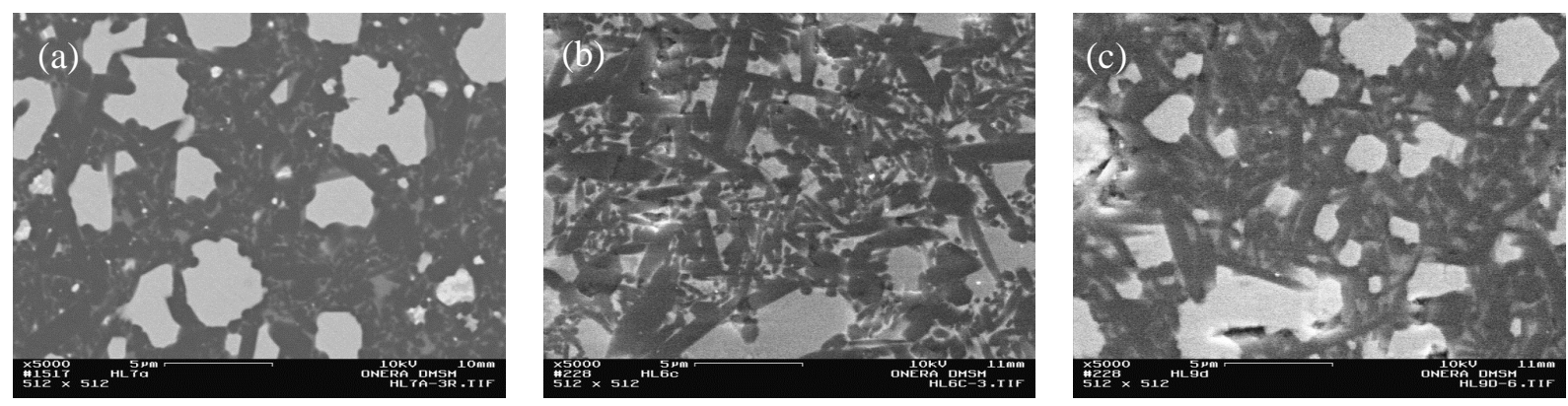

Figure 1: Microstructures of (a) SM73AY, (b) SM73Lu, (c) SM73MC materials.

\subsection{Mechanical properties}

Room temperature flexural strength, Young's modulus, hardness and indentation fracture toughness are shown in Table 3. Hardness values are quite similar for all compositions. Normally, $\mathrm{MoSi}_{2}$ lowers the hardness, but the compositions with high amount of $\mathrm{MoSi}_{2}$ have undergone an only partial $\alpha-\beta \mathrm{Si}_{3} \mathrm{~N}_{4}$ phase transition and the $\alpha$-phase is harder, so it is difficult to conclude.

Significant differences in strengths are observed as a function of sintering aids and the amount of $\mathrm{Si}_{3} \mathrm{~N}_{4}$. The best flexural strengths are reached for materials with $\mathrm{Lu}_{2} \mathrm{O}_{3}$ additives and the best toughness for composites with $\mathrm{Lu}_{2} \mathrm{O}_{3}$ and $\mathrm{MgO}-\mathrm{CeO}_{2}$. Previous studies have already evidenced the increase of $\mathrm{K}_{\mathrm{IC}}$ with the introduction of $\mathrm{MoSi}_{2}$ [19][20]. However, it was also shown that for high content of $\mathrm{MoSi}_{2}$, toughness decreases. This amount of $\mathrm{MoSi}_{2}$ depends on the particles size and ranges from 30 to $50 \mathrm{vol} \%$ [19][20][21]. The larger the grain size, the higher the amount of $\mathrm{MoSi}_{2}$. 


\begin{tabular}{cccccc}
\hline Composition & $\boldsymbol{\alpha} / \boldsymbol{\beta} \mathbf{W t} \%$ & $\boldsymbol{\sigma}_{\mathbf{f}}(\mathbf{M P a})$ & $\mathbf{E}(\mathbf{G P a})$ & $\mathbf{H v}(\mathbf{G P a})$ & $\mathbf{K}_{\mathbf{c}}\left(\mathbf{M P a} \cdot \mathbf{m}^{\mathbf{1} / 2}\right)$ \\
\hline SM55AY & 3.11 & $685 \pm 94$ & $331 \pm 2$ & $14.4 \pm 1.4$ & $4.6 \pm 0.3$ \\
SM55Lu & 1.22 & $825 \pm 20$ & $350 \pm 2$ & $14.5 \pm 0.2$ & $6.6 \pm 0.3$ \\
SM55MC & $>0$ & $553 \pm 7$ & $323 \pm 11$ & $12.9 \pm 0.1$ & $3.9 \pm 0.2$ \\
SM73AY & 0 & $775 \pm 25$ & $307 \pm 9$ & $13.5 \pm 0.1$ & $5.3 \pm 0.1$ \\
SM73Lu & 0 & $955 \pm 82$ & $323 \pm 2$ & $13.9 \pm 0.1$ & $6.4 \pm 0.2$ \\
SM73MC & 0 & $717 \pm 110$ & $302 \pm 1$ & $13.4 \pm 0.5$ & $7.9 \pm 1.0$ \\
\hline
\end{tabular}

Table 3: XRD and mechanical properties of $\mathrm{Si}_{3} \mathrm{~N}_{4}-\mathrm{MoSi}_{2}$ samples.

Results for composites with $\mathrm{AY}$ and $\mathrm{MC}$ sintering aids are in good agreement with these studies but in the case of composites with $\mathrm{Lu}_{2} \mathrm{O}_{3}$, toughness is stable with the amount of $\mathrm{MoSi}_{2}$. Toughness values vary from 3 to $7 \mathrm{MPa} \cdot \mathrm{m}^{1 / 2}$ for commercial hot pressed $\mathrm{Si}_{3} \mathrm{~N}_{4}$ and from 2.5 to $5 \mathrm{MPa} \cdot \mathrm{m}^{1 / 2}$ for $\mathrm{MoSi}_{2}$ [21],[22]. One of the main interests of $\mathrm{MoSi}_{2}$ is the strong rise in toughness observed with temperature, due to its brittleductile transition $\left(\sim 1000^{\circ} \mathrm{C}\right)$, while $\mathrm{Si}_{3} \mathrm{~N}_{4}$ maintains the same toughness as temperature is increased [22]. Crack paths have been observed for some samples: SM55Lu, SM73Lu and SM73MC (Figure 2).
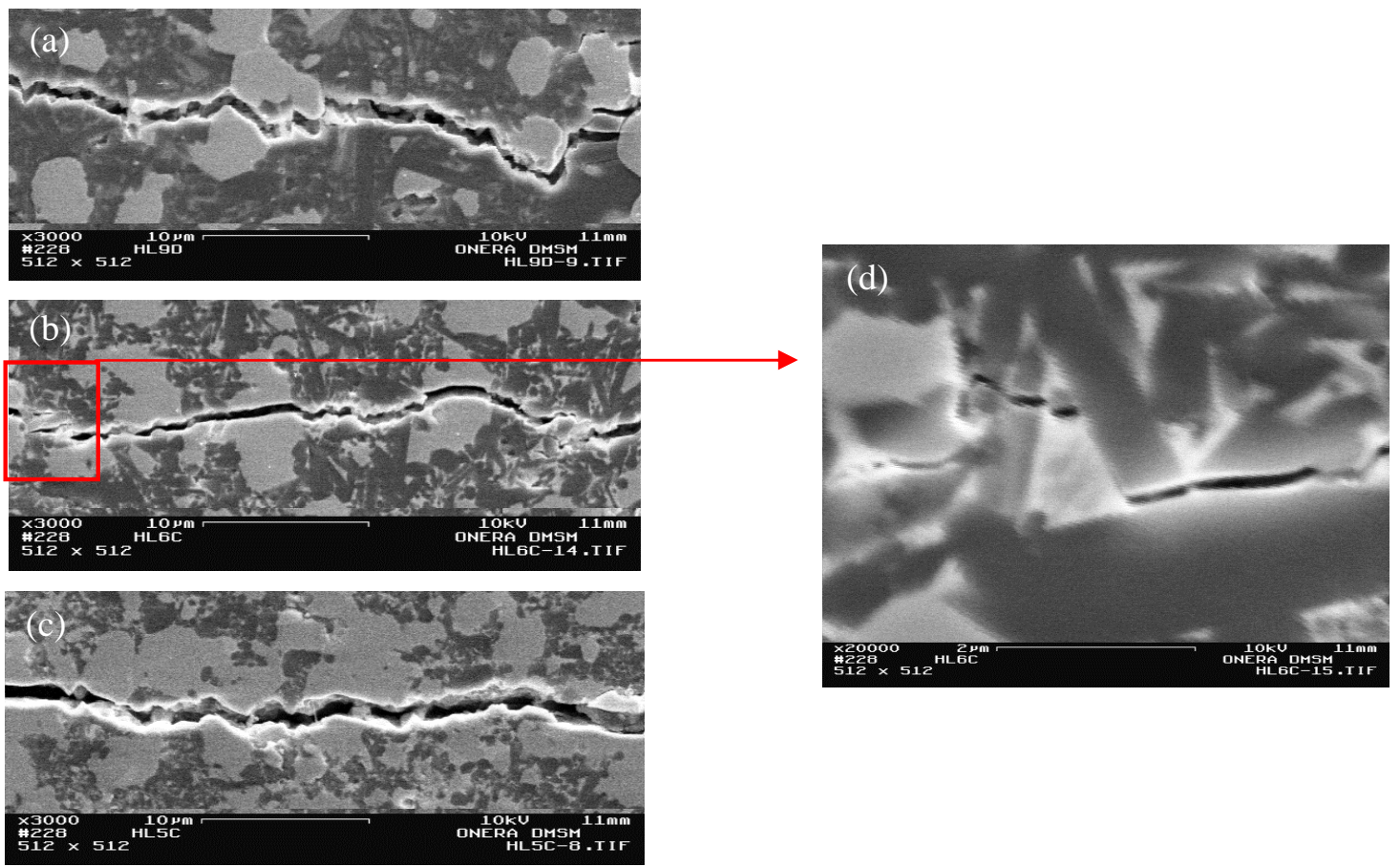

Figure 2: Crack paths in (a) SM73MC, (b) SM73Lu, (c) SM55Lu and (d) zoom of SM73Lu.

For SM73MC, the crack path is quite tortuous with some transgranular cleavages of $\mathrm{MoSi}_{2}$ and some crack deflections (i.e. the crack path follows the $\mathrm{MoSi}_{2}-\mathrm{Si}_{3} \mathrm{~N}_{4}$ phase boundary). For $\mathrm{SM} 73 \mathrm{Lu}$, the crack path seems less tortuous and only transphase. However, at the end of the crack, we can observe crack deflection due to rod-like shape of $\beta-\mathrm{Si}_{3} \mathrm{~N}_{4}$ phase. For SM55Lu, the crack path is quite linear and only transgranular through $\mathrm{MoSi}_{2}$ particles. Petrovic et al. explain that, as $\mathrm{MoSi}_{2}$ has a lower toughness compared to $\mathrm{Si}_{3} \mathrm{~N}_{4}$, fracture propagates easily through this phase. As the content of $\mathrm{MoSi}_{2}$ increases, the propagation of the cracks through this phase becomes easier and easier. Consequently, in most cases, a decrease in toughness is observed with the rise in $\mathrm{MoSi}_{2}$ content, but other parameters are to be taken into account such as: the nature of the additives and the grain growth of the acicular $\mathrm{Si}_{3} \mathrm{~N}_{4}$ phase. Indeed, for a same amount of $\mathrm{MoSi}_{2}$, we can notice in figure 1 that grain growth of $\beta-\mathrm{Si}_{3} \mathrm{~N}_{4}$ is larger for SM73Lu and SM73MC materials and higher toughness are measured. Moreover, the grain growth of $\beta-\mathrm{Si}_{3} \mathrm{~N}_{4}$ can also explain the lower toughness obtained with SM55AY and SM55MC materials where $\alpha-\mathrm{Si}_{3} \mathrm{~N}_{4}$ is still detected in huge quantity and particles of $\beta-\mathrm{Si}_{3} \mathrm{~N}_{4}$ are not rod-like due to a slight grain growth. In the case of SM55Lu and SM73Lu, toughness is quite similar for both materials and a crystalline boundary phase is detected. In conclusion, this boundary phase may have a strong influence on toughness, but this hypothesis has to be confirmed. 


\section{Directionally solidified eutectics}

\subsection{Context}

The investigation, which is focused on both binary $\mathrm{Al}_{2} \mathrm{O}_{3}-\mathrm{GdAlO}_{3}$ (GAP) and ternary $\mathrm{Al}_{2} \mathrm{O}_{3}-\mathrm{YAG}-\mathrm{ZrO}_{2}$ (A/YAG/Z) eutectics, has been performed in close relation with the CNRS-ICMPE Laboratory [23]-[32]. The most representative results concerning the microstructures and mechanical properties such as crack propagation and toughness are presented in order to evaluate the potential of DSE ceramics. In this respect, a biaxial testing disc flexure device has been designed to investigate the crack propagation modes in the various phases and in the interfaces [24][28][31]. These observations have been correlated to internal stress calculations and piezo-spectroscopy internal stress measurements [24][25][28][31].

\subsection{Processing and experimental means}

These DSE ceramics were grown from the melt using either the floating-zone method (arc image furnace) [23][24] or a specific Bridgman furnace designed by Cyberstar (Grenoble, France) according to the specifications established by Onera. This device, which includes two superposed radiofrequency heating elements, is able to produce large eutectic crystals (up to $50 \mathrm{~mm}$ in diameter and $200 \mathrm{~mm}$ in height) and turbine blades [32].

\subsection{Microstructures}

Under controlled conditions, solidification from the melt leads to materials free of porosity and with only very few grain boundaries, which are generally at the origin of brittleness in sintered ceramics. SEM images of the microstructures in cross-sections perpendicular or parallel to the solidification direction of binary and ternary eutectics are shown in Figure 3 [23][24]. In each case, continuous networks of two single-crystal phases are observed: $\mathrm{Al}_{2} \mathrm{O}_{3}$ (dark contrast) and a perovskite (GAP) or garnet (YAG) phase (bright contrast). The same morphology of continuous networks of two single-crystal phases is observed on sections parallel to the growth direction (Figure $3 \mathrm{left}$ ). It should be noted that the phases are not elongated in the growth direction, but perfectly similar in shape and size in sections parallel or perpendicular to the growth direction, thus revealing the three-dimensional configuration of the microstructure. The two phases interpenetrate without grain boundaries, pores or colonies.

The $\mathrm{Al}_{2} \mathrm{O}_{3}$-YAG- $\mathrm{ZrO}_{2}$ ternary eutectic displays a fine microstructure with curved smooth interfaces (Figure 3 right), instead of the coarser microstructure with large planar interfaces and sharp angles observed in the $\mathrm{Al}_{2} \mathrm{O}_{3}$-YAG binary eutectic [28][31]. In the $\mathrm{Al}_{2} \mathrm{O}_{3}-\mathrm{YAG}-\mathrm{ZrO}_{2}$ ternary eutectic, the cubic zirconia phase grows essentially at the interface between $\mathrm{Al}_{2} \mathrm{O}_{3}$ and $\mathrm{YAG}$, but also in the alumina phase (more clearly evidenced at a higher magnification, in Figure 4 (right), reporting crack propagation modes in the ternary eutectic).
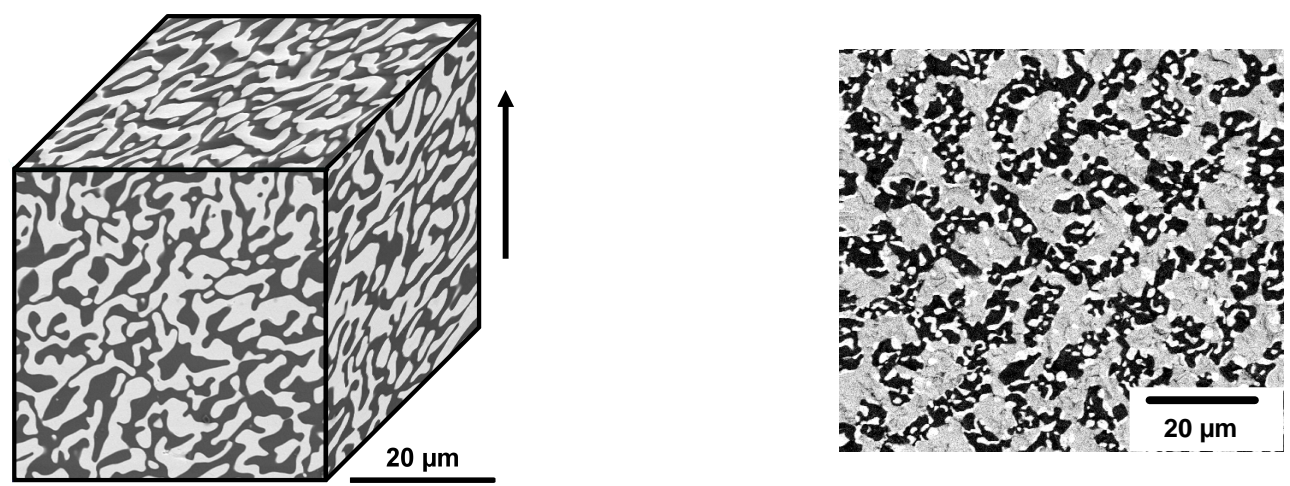

Figure 3: SEM micrographs revealing (left) the three-dimensional configuration of the microstructure of the $\mathrm{Al}_{2} \mathrm{O}_{3}$ GAP eutectic composite (the growth direction is indicated by the vertical arrow) and (right) the transverse section of the ternary eutectic containing $\mathrm{Al}_{2} \mathrm{O}_{3}$ (dark contrast), $\mathrm{YAG}$ (grey) and $\mathrm{ZrO}_{2}$ (bright dots). 


\subsection{Mechanical properties}

Improving the strength and toughness of eutectic ceramics requires a better knowledge of the crack propagation modes in such an interconnected microstructure. In this respect, a biaxial disc flexure testing device has been designed and built at Onera [28]. In the directionally solidified eutectics [28][31] investigated, the essential propagation mode is transgranular crack propagation (Figure 4). A zigzag crack growth with multiple branches is observed in most cases. However, this type of crack propagation does not only result from deflections of the cleavage crack inside each phase, or when crossing phase boundaries, but more essentially from crack deflection in the interfaces themselves. Interface crack propagation is thus observed between $\mathrm{Al}_{2} \mathrm{O}_{3}$ and GAP (large black arrow in Figure 4 left), $\mathrm{Al}_{2} \mathrm{O}_{3}$ and $\mathrm{ZrO}_{2}$ (white arrows in Figure 4 right), GAP and $\mathrm{ZrO}_{2}$ (sharp black arrow in Figure 4 right). Crack branching is observed, not only in one of the various phases such as $\mathrm{ZrO}_{2}$ (split arrow in Figure 4 right), but also in the interfaces where crack deflection through debonding has occurred (split arrows in Figure 4 left). In most cases, these bifurcation mechanisms lead to stopped cracks [28][31].
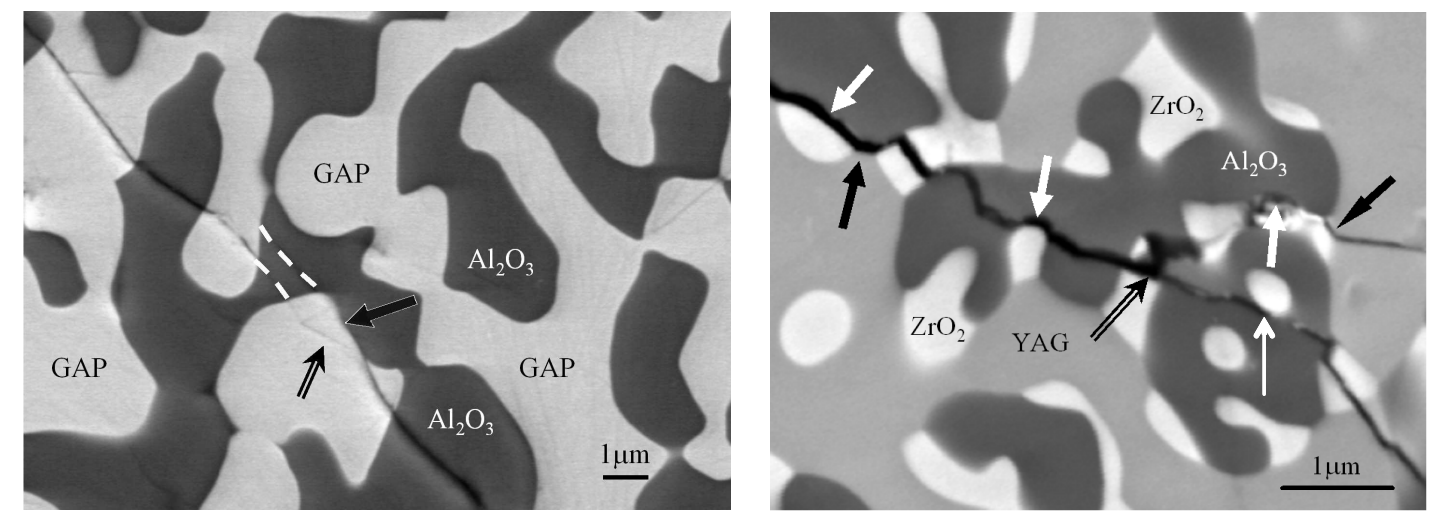

Figure 4: Crack propagation modes at room temperature in eutectic ceramics subjected to biaxial flexure (FEG-SEM, back-scattered electrons): $\mathrm{Al}_{2} \mathrm{O}_{3} / \mathrm{GAP}$ (left) and $\mathrm{Al}_{2} \mathrm{O}_{3} / Y A G / \mathrm{ZrO}_{2}$ (right).

The various crack propagation modes may be correlated to internal thermal stress measurements and calculations [28][31]. For instance, the presence of $\mathrm{ZrO}_{2}$ phases surrounded by a continuous layer of $\mathrm{Al}_{2} \mathrm{O}_{3}$ (Figure 4 right, low right corner) suggests the use of a concentric cylinder model (Figure 5 left). For instance, the $\mathrm{ZrO}_{2}$ phase in Figure 4 right may be represented by a $1 \mu \mathrm{m}$ in diameter $\mathrm{ZrO}_{2}$ bar, bonded into a $1.5 \mu \mathrm{m}$ thick $\mathrm{Al}_{2} \mathrm{O}_{3}$ sleeve, surrounded by a $0.5 \mu \mathrm{m}$ thick $\mathrm{ZrO}_{2}$ sleeve, these three concentric cylinders being embedded into an equivalent homogeneous medium (EHM) having the diameter of the specimen under investigation and the macroscopic thermo-mechanical properties of the bulk $\mathrm{Al}_{2} \mathrm{O}_{3}-\mathrm{YAG}-\mathrm{ZrO}_{2}$ eutectic. If this ternary eutectic is subjected to a temperature change $\left(\Delta \mathrm{T} \approx 1700^{\circ} \mathrm{C}\right)$, then the normal stress $\left(\sigma_{\mathrm{n}}=\sigma_{\mathrm{r}}\right)$ acting on the $\mathrm{ZrO}_{2}-\mathrm{Al}_{2} \mathrm{O}_{3}$ interface attains $\approx 1200 \mathrm{MPa}$; this high tensile normal stress helps interface crack propagation, as observed in Figure 4 (right, thin white arrow). The external $\mathrm{ZrO}_{2}$ layer is subjected to a high tensile circumferential loading $\left(\sigma_{\theta} \approx 1800 \mathrm{MPa}\right)$ which helps transgranular crack propagation in these phases [24][28][31].
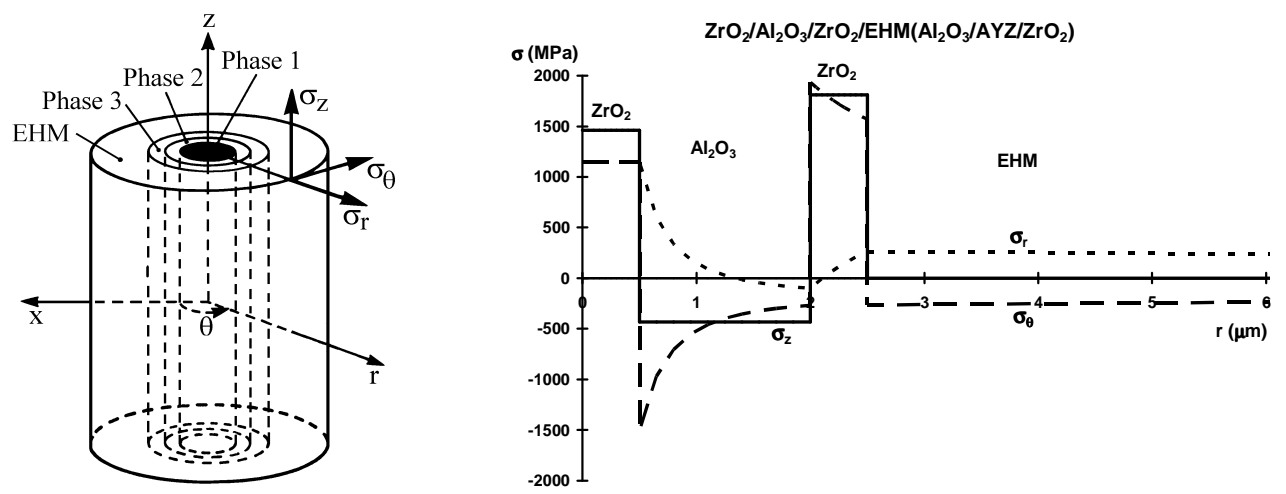

Figure 5: Internal thermal stresses. The four-phase concentric cylinder model (a), the corresponding stress system (b), where the normal stress $\sigma_{n}$ is given by the radial stress component $\sigma_{r}$. 
As compared to the ultimate tensile strength of such eutectic ceramics [14], the level of these internal thermal stress components is very high, which may explain their essential role in crack nucleation and propagation (e.g. the possibility of crack deflection in the interfaces, in the ternary eutectic ceramics). This high stress level is however in good agreement with the internal stress measurements performed through ruby $\left(\mathrm{Cr}^{3+}\right)$ fluorescence piezo-spectroscopy [31]. The fact that the observed crack deflection modes are more numerous in ternary than in binary eutectics is in good agreement with the fact that the fracture toughness is improved from the individual constituents, to the binary eutectics $\left(\approx 7 \mathrm{MPa} \mathrm{m}{ }^{1 / 2}\right)$ and to the ternary eutectics $\left(\approx 10 \mathrm{MPa} \mathrm{m}^{1 / 2}\right)[23]$.

Moreover, factors other than the thermal mismatch stresses, such as the role of the Young's modulus ratio between garnet or perovskite and alumina, as well as the nature of the interfaces, have a non-negligible effect on the crack deflection and propagation modes [31]. Consequently, due to the presence of a two- or three-phase 3-D interconnected microstructure, a highly detrimental crack propagation mode such as transgranular crack propagation in the brittle ceramic phases is drastically limited by energy dissipative crack deflection modes resulting from thermal mismatch stresses, the effects of Young's modulus ratios and the nature of the interfaces between the various phases [28][31].

Compressive creep tests have been performed on the binary and ternary eutectics under consideration (stress range 50 to $200 \mathrm{MPa}$, temperature range 1450 to $1600^{\circ} \mathrm{C}$ ). The creep strain rate of $\mathrm{Al}_{2} \mathrm{O}_{3}-\mathrm{YAG}-\mathrm{ZrO}_{2}$ eutectic is similar to that of the $\mathrm{Al}_{2} \mathrm{O}_{3}$-GAP eutectic. The TEM examinations have evidenced plastic deformation of the various phases; furthermore, the different deformation modes thus observed are in good agreement with the stress exponents and activation energies experimentally determined [29][30][32].

\section{Conclusion}

Regarding the development of $\mathrm{Si}_{3} \mathrm{~N}_{4}-\mathrm{MoSi}_{2}$ composites, two relative proportions of each component with three kinds of sintering aids have been manufactured as dense ceramics using spark plasma sintering. High mechanical properties have been reached, especially high toughness $\left(6-8 \mathrm{MPa} \cdot \mathrm{m}^{1 / 2}\right)$ is obtained for materials with 70 vol. $\%$ of $\mathrm{Si}_{3} \mathrm{~N}_{4}$ with $\mathrm{Lu}_{2} \mathrm{O}_{3}$ and $\mathrm{MgO}-\mathrm{CeO}_{2}$ as additives. Toughness can still be improved controlling microstructure and grain growth of $\beta-\mathrm{Si}_{3} \mathrm{~N}_{4}$. Further developments are in progress.

Ceramic materials prepared by unidirectional solidification of oxides from the melt are under investigation at Onera for applications in the aerospace field and in particular for gas turbine blades. Studies to control the microstructure of these eutectic ceramics have been performed. The mechanical properties have been investigated with the aim of understanding the toughening mechanisms and the creep behavior at high temperatures. In the ternary eutectic ceramics, the high level of the internal thermal stresses may explain their essential role in crack nucleation and propagation (e.g. the possibility of crack deflection in the interfaces). The fact that the observed crack deflection modes are more numerous in ternary than in binary eutectics is in good agreement with the improvement of the fracture toughness from the individual constituents, to the binary eutectics and to the ternary eutectics. This better knowledge of the behavior of DSE ceramics subjected to thermomechanical loadings has led to the development of a specific Bridgman furnace to produce large crystals and turbine blades.

\section{Acknowledgements}

The authors want to thank the European Commission for partially funding the HYSOP project and MM. Bonnefont and Fantozzi from MATEIS Laboratory for Spark Plasma sintering and fruitful discussions.

\section{References}

[1] H. Klemm, Silicon nitride for high temperature applications, J. Amer. Ceram. Soc. 93 pp. 1501-1522 (2010).

[2] H. Klemm and C. Schubert, Silicon nitride/molybdenum disilicide composite with superior long term oxidation resistance at $1500^{\circ}$ C, J. Amer. Ceram. Soc. 84 pp. 2430-2432 (2001).

[3] H. Klemm, M. Herrmann and C. Schubert, Silicon nitride composites materials with an improved high temperature oxidation resistance, Ceram. Eng. Sci. Proceedings 18 pp. 615-623 (1997).

[4] K. Sadananda, C. R. Feng, R. Mitra and S. C. Deevi, Creep and fatigue properties of high temperature silicides and their composites, Mater. Sci. Eng. A261 pp. 223-238 (1999).

[5] K. Yamada and N. Kamiya, High temperature mechanical properties of $\mathrm{Si}_{3} \mathrm{~N}_{4}-\mathrm{MoSi}_{2}$ and $\mathrm{Si}_{3} \mathrm{~N}_{4}-\mathrm{SiC}$ composites with network structures of second phases, Mater. Sci. Eng. A261 pp. 270-277 (1999). 
[6] K. Bundschuh, M. Schüze, C. Muller, P. Greil and W. Heider, Selection of materials for use at temperatures above $1500^{\circ} \mathrm{C}$ in oxidizing atmospheres, J. Eur. Ceram. Soc. 18 pp. 2389-91 (1998).

[7] Z. Yao, J. Stiglich and T. S. Sudarshan, Molybdenum silicide based materials and their properties, J. Mater. Eng. Performances 8 pp. 291-304 (1999).

[8] C. G. McKamey, P. F. Tortorelli, J. H. DeVan and C. A. Carmichael, A study of pest oxidation in polycrystalline $\mathrm{MoSi}_{2}$, J. Mater. Research 7 pp. 2747-2755 (1992).

[9] T. Hsieh, H. Choe, E. J. Lavernia and J. Wolfenstine, The effect of $\mathrm{Si}_{3} \mathrm{~N}_{4}$ on the thermal expansion behavior of $\mathrm{MoSi}_{2}$, Materials Letters 30 pp. 407-410 (1997).

[10] M. G. Hebsur, Development and characterization of $\mathrm{SiC}(\mathrm{f}) / \mathrm{MoSi}_{2}-\mathrm{Si}_{3} \mathrm{~N}_{4}(\mathrm{P})$ hybrid composites, Mater. Sci. Eng. A261 pp. 24-37 (1999).

[11] S. Drawin and J. F. Justin, Advanced lightweight silicide and nitride based materials for turbo-engine applications, AeropsaceLab AL 03 -06 (2011).

[12] Y. Waku, N. Nakagawa, T. Wakamoto, H. Ohtsubo, K. Shimizu and Y. Kohtoku, A ductile ceramic eutectic composite with high strength at 1873K, Nature 389 pp. 49-52 (1997).

[13] J. Llorca and V. M. Orera, Directionally solidified eutectic ceramic oxides, Prog. Mater. Sci. 51 pp. 711-809 (2006).

[14] J. I. Peña, M. Larson, R. I. Merino, I. de Francisco, V. M. Orera， J. Llorca， J. Y. Pastor， A. Martín and J. Segurado, Processing, microstructure and mechanical properties of directionally-solidified $\mathrm{Al}_{2} \mathrm{O}_{3}-\mathrm{Y}_{3} \mathrm{Al}_{5} \mathrm{O}_{12}-$ $\mathrm{ZrO}_{2}$ ternary eutectics, J. Eur. Ceram. Soc. 26 pp. 3113-3121 (2006).

[15] N. Nakagawa, H. Ohtsubo, A. Mitani, K. Shimizu and Y. Waku, High temperature strength and thermal stability for melt growth composite, J. Eur. Ceram. Soc. 25 pp. 1251-1257 (2005).

[16] Y. Waku, S. Sakata, A. Mitani, K. Shimizu and M. Hasebe, Temperature dependence of flexural strength and microstructure of $\mathrm{Al}_{2} \mathrm{O}_{3} / \mathrm{Y}_{3} \mathrm{Al}_{5} \mathrm{O}_{12} / \mathrm{ZrO}_{2}$ ternary melt growth composites, J. Mater. Sci. 37 pp. 2975-2982 (2002).

[17] K. Hirano, Application of eutectic composites to gas turbine system and fundamental fracture properties up to $1700^{\circ}$ C, J. Eur. Ceram. Soc. 25 pp. 1191-1199 (2005).

[18] J. J. Petrovic, M. I. Pena and H. H. Kung, Fabrication and microstructures of $\mathrm{MoSi}_{2}$ reinforced-Si ${ }_{3} \mathrm{~N}_{4}$ matrix composites, J. Amer. Ceram. Soc. 80 pp. 1111-1119 (1997).

[19] D. Scitti, S. Guicciardi and A. Bellosi, Properties of $\mathrm{Si}_{3} \mathrm{~N}_{4}-\mathrm{MoSi}_{2}$ composites with a nanostructured matrix, $J$. Mater. Research 23 pp. 673-679 (2002).

[20] J. J. Petrovic, M. I. Pena, I. E. Reimanis, M. S. Sandlin, S. D. Conzone, H. H. Kung and D. P. Butt, Mechanical behavior of $\mathrm{MoSi}_{2}$ reinforced-Si $\mathrm{N}_{3}$ matrix composites, J. Amer. Ceram. Soc. 80 pp. 3070-3076 (1997).

[21] M.-Y. Kao, Properties of silicon nitride-molybdenum disilicide particulate ceramic composites, J. Amer. Ceram. Soc. 76 pp. 2879-2883 (1993).

[22] M. G. Hesbur, Strong, tough, and pest resistant $\mathrm{MoSi}_{2}$-base hybrid composite for structural applications, NASA technical memorandum 107471 (1997).

[23]N. Piquet, Microstructures interconnectées dans des eutectiques à base d'oxydes réfractaires élaborés par solidification dirigée, Doctorate thesis, Univ. Paris XII (2006).

[24]L. Perrière, Elaboration par solidification dirigée et comportement mécanique de céramiques eutectiques à base d'oxydes réfractaires. Rôle de la microstructure sur la fissuration et la déformation plastique à haute temperature, Doctorate thesis, Univ. Paris-Est (2008).

[25] G. Gouadec, Ph. Colomban, N. Piquet, M. F. Trichet and L. Mazerolles, Raman/Cr3+ fluorescence mapping of a melt-grown $\mathrm{Al}_{2} \mathrm{O}_{3} / \mathrm{GdAlO}_{3}$ eutectic, J. Eur. Ceram. Soc. 25 pp. 1447-1453 (2005).

[26] L. Mazerolles, N. Piquet, M. F. Trichet and M. Parlier, Microstructures and interfaces in melt-growth $\mathrm{Al}_{2} \mathrm{O}_{3}-$ $\mathrm{Ln}_{2} \mathrm{O}_{3}$ based eutectic composites, Adv. Sci. Techn. 45 pp. 1377-1384 (2006).

[27] L. Mazerolles, N. Piquet, M. F. Trichet, L. Perrière, D. Boivin and M. Parlier, New microstructures in ceramic materials from the melt for high temperature applications, Aerospace Sci. Techn. 12 pp. 499-505 (2008).

[28] L. Perrière, R. Valle, L. Mazerolles and M. Parlier, Crack propagation in directionally solidified eutectic ceramics, J. Eur. Ceram. Soc. 28, pp. 2337-2343 (2008).

[29] L. Mazerolles, L. Perrière, S. Lartigue-Korinek, N. Piquet and M. Parlier, Microstructures, crystallography of interfaces and creep behavior of melt-growth composites, J. Eur. Ceram. Soc. 28 pp. 2301-2308 (2008).

[30] L. Mazerolles, L. Perriere, S. Lartigue-Korinek and M. Parlier, Creep behavior and related structural defects in $\mathrm{Al}_{2} \mathrm{O}_{3}-\mathrm{Ln}_{2} \mathrm{O}_{3}\left(\mathrm{ZrO}_{2}\right)$ directionally solidified eutectics $(\mathrm{Ln}=\mathrm{Gd}, \mathrm{Er}, \mathrm{Y})$, J. Eur. Ceram. Soc. 31, pp. 1219-1225 (2011).

[31] L. Perrière, R. Valle, N. Carrère, G. Gouadec, Ph. Colomban, S. Lartigue-Korinek, L. Mazerolles and M. Parlier, Crack propagation and stress distribution in binary and ternary directionally solidified eutectic ceramics, J. Eur. Ceram. Soc. 31 pp. 1199-1210 (2011).

[32] M. Parlier, R. Valle, L. Perrière, S. Lartigue-Korinek and L. Mazerolles, Potential of directionally solidified eutectic ceramics for high temperature applications, AerospaceLab AL 03 -07 (2011). 



\section{ONERA}

BP 72 - 29 avenue de la Division Leclerc - 92322 CHATILLON CEDEX - Tél. : +33 146734040 - Fax : +33 146734141

w w w. onera.f r 